\section{ЛIТЕРАТУРА}

1. Зельвенский С. Mocumentary: история вопроса. // Сеанс. 2007. [Электронный ресурс]. URL: http://seance.ru/n/32/ mockumentary/mocumentary/ (дата обращения 07.04.2018).

2. Тарковский А. Запечатленное время. // Вопросы киноискусства. - Вып. 10. / А. Тарковский. -М., 1967.С 69-91.

3. Хохлова Е. В. Мокьюментари: синтез документального и художественного (на примереромана “Артур и Джордж”) / Е. В. Хохлова // Вестник Нижегородского университета им. Н.И. Лобачевского. - 2013, №6 (2), С. 296-300.

4. Чайка М. А. Мок’ юментарі, як “особливий” стиль кіновиробництва / Мирослава Чайка // Науковий вісник Миколаївського національного університету імені В. О. Сухомлинського. Педагогічні науки. - 2018. - №2 (61). C. $310-315$.

5. Ширман Р.Н. Умное телевидение. / Роман Ширман.-Киев: Телерадиокурьер, 2011. -359 с.

\section{REFERENCES}

1. Zelvenskiy, S. (2007). Mocumentary: istoriya voprosa [Mocumentary: the history of the issue]. Kyiv:

Seans, 32. Retrieved from http://seance.ru/n/32/ mockumentary/mocumentary/ [in Russian].

2. Tarkovskiy, A. (1967). Zapechatlennoe vremya [Imprinted time]. Moscow: Voprosy kinoiskusstva, Vol.10, pp.69-91. [in Russian].

3.Khokhlova, E. (2013). Mocumentary: syntez dokumentalnoho y khudozhestvennoho (na prymere romana “Artur y Dzhordzh") [Mocumentary: synthesis documentary and artistic (there are "Arthur and George" on the example of novel)]. Bulletin of Nyzhniy Novhorod University named after N.I. Lobachevskiy, No. 6 (2), pp. 296-300. [in Russian].

4.Chaika, M. A. (2018). Mokiumentari, yak "osoblyvyi" styl kinovyrobnytstva [Mockumentary, as a "special" style of film production]. A scientific herald of Mykolayiv Vasyl Sukhomlynskiy National University. Pedagogical sciences, No.2 (61), pp. 310-315. [in Ukrainian].

5. Shirman, R. N. (2011). Umnoetelevidenie [Smart television]. Kiev: Teleradiokurer, 359 p. [in Russian].

Стаття надійшла до редакції 14.11.2018

УДК 377.016:821.161.2.09

DOI:

Уляна Пріць, викладач української мови та літератури, завідувач навчально-методичного кабінету Самбірського технікуму економіки та інформатики

\title{
НЕСТАНДАРТНІ ПІХОДИ ДО ВИВЧЕННЯ УКРАЇНСЬКОЇ ЛІТЕРАТУРИ
}

У статті розглядаються особливості нестандартних підходів до вивчення украйнської літератури у коледжах, сприймання літературних творів студентською молоддю, закономірності формування читаџьких умінь, які удосконалюються в прочесі навчання, необхідних для розуміння й осягнення змісту літературних художніх творів. Зосереджено увагу на становленні форм організації системи навчання, спробах удосконалити заняття як специфічну форму організаиї навчально-виховного процесу.

Ключові слова: сприймання; пізнання; творчі здібності; мовні компетенції; дискусія.

Jim. 9.

Ulyana Prits, Lecturer of the Ukrainian Language and Literature, Head of the Educational and Methodical Cabinet Sambir Technical School of Economics and Computer Sciences

\section{NON-STANDARD APPROACHES TO THE STUDYING OF UKRAINIAN LITERATURE}

The article deals with the peculiarities of non-standard approaches to the studying of Ukrainian literature in colleges, the perception of literary works by students, as well as regularities of the formation of readers' skills that are necessary for understanding and comprehension of the content of literary works which are improved in the process of studies.

Understanding the importance of education, the need to reform its system, access to higher quality and spirituality, as well as the search for new ways in the educational space are the main tasks of the teacher in the present.

The article focuses on the formation of organization forms in the system of studies, attempts to improve the lessons as a specific form of organization of the educational process. The teachers of the Ukrainian language and literature face a number of tasks: to reveal to students the beauty of their native language, to teach them the correct literary pronunciation, to help to understand the belonging to a great tradition through the literary aspect, to develop a sense of pride for their nation, and to discover their personal creative potential.

According to many modern linguists and literary critics, within the competent paradigm in education, it is critical to form linguistic competences of students, to develop practical skills of language culture, to instill language 
tastes by expanding the literary world, to broaden the students' knowledge about Ukrainian language and literature, and to develop language and literary reflection skills on lessons of the Ukrainian language and literature.

Thus, the issue of the formation of active cognitive activity, the emotional education and personal orientation of students can be solved by applying non-standard, active forms, methods, and techniques of teaching literature. Keywords: perception; cognition; creative abilities; language competences; discussion.

П остановка проблеми. Сучасний світ сьогодні, соціальне середовище, в якому живе людина i яке безпосередньо впливає на формування особистості - $\epsilon$ доволі складною системою взаємозв'язків та суперечностей. Розуміння значення освіти, необхідності реформування іiі системи, вихід на вищу якість та духовність, пошук нових шляхів в освітянському просторі одне з основних завдань педагога у сьогоденні. Не секретом $є$ те, що викладач повинен самотужки створювати методичне забезпечення дисципліни, завжди перебувати у пошуку нових форм і методів викладання свого предмета. Саме 3 цією метою варто звертатися до нестандартних підходів у викладанні, які спрямовані на розвиток гармонійної особистості, іiі творчих здібностей та критичного мислення.

Аналіз основних досліджень та публікацій. Становлення форм організації системи навчання здійснювалось 3 розвитком суспільства. Першим, як відомо, виникло індивідуальне навчання, згодом з'явився індивідуально-груповий спосіб. Наприкінці XVI - на початку XVII ст. в школах України, Білорусії, Польщі та деяких інших країнах почали застосовувати групове навчання, що стало основою класно-урочної форми навчання, обгрунтованої Я. Коменським. Та незважаючи на широке визнання в світі класно-урочної системи, вона все ж має багато недоліків. Перед викладачами української мови та літератури постає чимало завдань: розкрити студентам красу рідної мови, навчити їх правильної літературної вимови, допомогти усвідомити приналежність до великої традиції через літературознавчий аспект, відтак виховати в них почуття гордості за свою націю, розкрити особистий творчий потенціал. Даний підхід із використанням нестандартних новітніх підходів при викладанні української літератури активно популяризується у педагогічному доробкуМ. Кларина, М. Пентилюк, I. Фомича, Б. Степанишина та ін. Окрім наукових теоретичних підходів до використання розглядуваних навчальних технологій вагомий внесок зробили викладачі-практики І. Кузьміна, О. Пометун, Л. Башманівська, Г. Токмань та iн.

Мета статті. Розкрити особливості нестандартних підходів до вивчення української літератури у коледжах, поділитися новими формами проведення занять, які є своєрідною модифікацією традиційних їх типів.

Виклад основного матеріалу. Чи може сучасне заняття з української літератури бути цікавим і захоплюючим для студентів та розкрити творчий потенціал особистості? Ствердно відповісти на це запитання можна лише за умови, якщо процес навчання перевести на інноваційну основу, змінивши сам підхід до здобуття знань 3 літератури. Саме новітнє навчання забезпечує позитивну мотивацію здобуття знань 3 літератури, дає відчуття потреби у самоосвіті, формує стійкий інтерес до дисципліни, сприяє розвитку творчої та самодостатньої особистості.

На думку багатьох сучасних мовознавців та літературознавців у рамках дії компетентнісної парадигми в освіті на заняттях української літератури і мови необхідно: формувати мовні компетенції студентів, виробляти практичні навички володіння культурою мови, додержання мовних норм, уміння користуватися словниками та іншою довідковою літературою; прищеплювати мовний смак, розширюючи літературний світогляд; розширювати знання студентів про українську мову та літературу; виробляти навички мовно-літературної рефлексії; формувати загальні мовленнєві компетенції, цілісне уявлення про мову як національно-культурний феномен, розуміння національної своєрідності української літератури, знання констант української національної культури тощо; формувати дослідницьку компетенцію, вдосконалювати вміння й навички самостійної роботи з літературним текстом.

Найголовніша риса сучасного навчання “ його направленість на те, щоб підготувати студентів не тільки пристосовуватись до життя, але й активно засвоювати ситуації соціальних змін. Це призводить до того, що все частіше прогресивні вчителі і методисти звертаються до нестандартних, активних форм, методів і прийомів викладання літератури, що дістало назву “інноваційне навчання". Це поняття відноситься не тільки до створення та розповсюдження нововведень, але і до таких змін, які мають сутнісний характер, супроводжуються змінами в образі діяльності, стилі мислення. Категорія новизни відноситься не стільки до часу, скільки до якісних рис змін. Серед таких змін можна виділити орієнтацію на активне засвоєння студентом засобів пізнавальної діяльності, 


\section{НЕСТАНДАРТНІПШДХОДИ ДО ВИВЧЕННЯ УКРАЇНСЬКОЇ ЛІТЕРАТУРИ}

орієнтацію навчання на особистість молодої людини, забезпечення можливостей його саморозкриття, адаптацію навчального процесу до запитів і потреб особистості. Якщо традиційне навчання пов'язане 3 ретрансляцією, відтворенням, то інноваційне “ $з$ творчим пошуком на основі існуючого досвіду і тим самим - 3 його збагаченням. Такому навчанню притаманний дослідницький підхід, творчий пошук, проблематизація, що забезпечує високу активність учнів [9]. Як зазначає М. Кларін, це “процес і результат такої навчальної і освітньої діяльності, яка стимулює вносити зміни в існуючу культуру, соціальну сферу" [3].

Інноваційні підходи до навчання можна розподілити на два основних типи, які відповідають репродуктивній та проблемній орієнтації навчального процесу. Відповідний пошуковий підхід до навчання спрямований передусім на формування у студентської молоді досвіду самостійного пошуку нових знань, їх використання унових умовах, формування досвіду творчої діяльності.

Проблему формування активної пізнавальної діяльності, виховання емоційно-почуттєвої сфери та особистісної орієнтації студентів можна розв'язати шляхом створення умов, коли сам студент буде йти до таємниць письменницької творчості і брати те, що йому потрібно. І зробити це можна шляхом активного й послідовного застосування прийомів проблемного навчання. Навчання, в основі якого лежить принцип проблематизації, спонукає до дискусії, яку Б. Степанишин справедливо називає “торжеством всієї методики вчителя" [7].

Головною рисою дискусії, на думку М. Кларіна, $\epsilon$ те, що вона має “цілеспрямований i упорядкований обмін ідеями, судженнями, думками у групі заради пошуку істини (точніше, істин), причому всі учасники беруть участь в організації цього обміну” [4].

На сучасному етапі реформування освіти, вивчення літератури грунтується на таких видах навчальної діяльності з набування знань як читання текстів художньої літератури; оволодіння новими, часто індивідуальними поглядами на проблематику творів; засвоєння літературознавчої теорії, що забезпечує наукове сприйняття літературного процесу; формування критичного ставлення до матеріалу 3 метою набуття особистого досвіду на прикладі життя героїв, а також формування вміння самостійно набувати знання і застосовувати їх не тільки в процесі аналізу літературних творів, але й у різноманітних життєвих ситуаціях.
Педагогу необхідно вибудовувати навчальний процес таким чином, щоб студенти заглиблювалися в атмосферу пошуку, вирішували поставлені проблеми на основі порівняння й зіставлення. Шляхом дослідження інтелектуальних і творчих особистісних якостей молодих людей викладач домагається диференціації, впливу на розвиток кожного студента 3 урахуванням його інтересів, мотивів, системи цінностей; створюючи неповторні групи 3 певним психологічним аспектом, стимулює розвиток здібностей кожної особистості. Для досягнення зазначеної мети варто проводити нестандартні заняття 3 української літератури: диспути, дослідження, спогади, семінари, заняття 3 використанням ігрових моментів, інтегровані заняття, а також бінарні заняття як форма реалізації інтегрованого навчання.

Таким чином, створивши передумови для всебічного розгляду студентами певних об'єктів дослідження, понять, художніх явищ; сформувавши певну систему мислення, позитивного емоційного ставлення до пізнання, викладач сприяє кращому засвоєнню матеріалу. Студенти повинні відчути, що, скажімо, заняття літератури має сенс, вписується в загальну картину - і їх особистого і загальнолюдського. Викладач непомітно робить для них перевірки або експерименти, які доводять студентам, що вони засвоїли матеріал, розуміють його, якого ніби і не намагалися вивчити. При цьому він повинен вживати і невербальні засоби спілкування: жести, міміку, інтонацію, паузи, спостерігати за процесами навчання, одночасно стежити за тим, наскільки студенти сприймають матеріал, чи не знижується їхні увага. Також викладач повинен духовно вивищувати молодих людей, але робити це слід непомітно, невимушено.

Часто на заняттях літератури викладач зауважує, як студент уміло дає естетичні, самостійні оцінки твору, свої міркування про нього. Але ще досить часто можна спостерігати, як студенти вправно оперують текстом твору, обгрунтовуючи свої думки, але не уявляють свого ставлення до змальованих письменником явищ. Повторюється міркування шкільного підручника (окремі думки, що прозвучали на заняттях), літературні герої, їх вчинки, дії, ідеї письменника ніби відгородженні від думок студента, є просто матеріалом для заучування. Незрілість естетичного розвитку студентів підліткового віку, відсутність у них сформованих критерії і смаків, чіткої естетичної позиції, з одного боку, і певні шаблонні форми роботи над словом, з другого, $\epsilon$ грунтом для розвитку дітей конформізму у 


\section{НЕСТАНДАРТНІ ПДХОДИ ДО ВИВЧЕННЯ УКРАЇНСЬКОЇ ЛІТЕРАТУРИ}

сприйнятті мистецтва. Це проявляється в бездумному прийнятті чужих висновків, міркувань, ідей тощо. Звідси і необхідність при вивченні літератури виховувати у молоді особистісне ставлення до твору, до вчинків героїв, до поставлених письменником проблем, давати їм змогу щиро висловитись, вдаватися до рефлексій, критичного мислення.

Всі висновки про художню майстерність митця повинні робитися лише на основі безпосередніх спостережень над текстом художніх творів. При цьому потрібно заглибитись у внутрішній світ персонажів, вміти зіставляти його зі світом, бути чутливим до проблем. Звідси випливає висновок про нетрадиційне викладання української літератури. Потрібно студентам створити такі умови, в котрих вони б проявляли більше ініціативи, а не просто “засвоювали” матеріал підручника, чи ту інформацію, яку передає викладач.

Скажімо доктор педагогічних наук М. Пентилюк зазначає, що нові підходи до технології заняття створюють сприятливі умови для розвитку творчості студентської молоді, формування мовної особистості й ставлять ряд вимог до вчителя, зокрема: уміння діагностувати цілі навчання, досконало володіти мовою, розробляти опорні конспекти, створювати нові види наочності, вільно володіти проблемним навчанням, організувати групову та індивідуальну роботу 3 використанням комп'ютерів [6]. Додати ще можна активізацію дослідницької діяльності, організацію навчально-ігрової, моделюючої діяльності, активний обмін думками, творчу дискусію. Кожен із зазначених інформаційних компонентів має власні виражальні засоби та дидактичні можливості, що спрямовані на забезпечення оптимізації процесу навчання, адже мультимедіа, скажімо, - це сучасна комп'ютерна інформаційна технологія, що дозволяє об'єднувати в одній комп'ютерній програмнотехнічній системі текст, звук, відеозображення, графічне зображення та анімацію.

Та дуже важливим є не плутати “поняття “методика уроку” і “технологія уроку”. Перша ставить перед учителем завдання: “Що вивчати? навіщо вивчати? де навчати?”, а друга - “як навчати?”. Технологію від методики відрізняють два принципових моменти: проектування майбутнього навчального процесу й гарантія кінцевого результату. 3 цього можна зробити висновок, що методика узагальнює досвід, а технологія проектується 3 урахуванням умов навчання та орієнтується на кінцевий результат" [6].
Основне завдання літератури - розвивати художнє (образне) мислення студентів, збагачувати їх здібність сприйняття новими образами. Олександр Дорошкевич (1889 - 1946) - літературознавець, педагог, критик у 20-х роках писав до словесників: яке “злочинство i насильство над юнацькою душею чинять ті, хто хоче обов'язково втлумачити студентам своє розуміння художнього твору, цілком не рахуючись 3 їхньої власною реакцією на внутрішні психічні подразнення у зв'язку зі сприйняття твору”. Він твердив, що прочитання образу героя залежить від “досвіду життя, певного рівня розумового розвитку, запасу життєвих спостережень, вродженої здібності інтуїтивно схоплювати образ, від соціального походження, віку, випадкового настрою”. Олександр Потебня теж заперечував вчителеві, який нав' язує своїм вихованням власне значення поетичного образу. Література, як і інше мистецтво перетворює дійсність в образ.

Дуже корисними і результативними засобами розвивати художнє (образне) мислення $є$ пошуковий і дослідницький методи навчання. Наприклад, якщо б студент працював над життєписом письменника не з одним підручником, а зі збірниками, де б були вміщені короткі біографічні відомості, щоденникові запаси, листи, спогади про автора, кілька літературно-критичних статей, факти до написання літературного твору, то йому б було легше зрозуміти твір, і ті проблеми, які змальовані в ньому. Тому на заняттях потрібно більше уваги приділяти проблемним запитанням.

Наприклад, за драмою-феєрією Лесі Українки "Лісова пісня":

- Чи змінилося б життя Мавки, якби вона поступилася своїми моральними принципами; як саме?

- Чому лісова Мавка не порушує “гармоніи”' реального навколишнього світу, а людина порушує гармонію в природі.

За романом І. Багряного “Тигролови”:

- На які випробування здатна людина аби вижити заради високої цілі?

- Ціною яких зусиль далася героям твору воля?

- Чому там, на Далекому Сході, за тисячі кілометрів від України, звучить народна пісня, збережені традиції, звичаї?

Принцип проблематизації навчання дає змогу пов'язати його з життям, навчити студента творчо мислити. Навчання, в основі якого лежить цей принцип, спонукає до дискусій. Результати дискусій не прогнозовані, їх важко передбачити. Тому потрібно дати можливість студентам висловити свої думки, поділитися своїми 
враженнями. Мета викладача в даній ситуації дійти до найкращого рішення.

Наприклад: при вивченні “Лісової пісні" Лесі Украӥнки можна звернути увагу на творчість художнииі Катерини Білокур. Мавка - фантастична істота, взята Лесею 3 казкового світу, сприймається як реальна. I на картинах К. Білокур, незвичайна чи фантастична композиція не порушує гармонії реального навколишнього світу. Візьмемо до уваги картину “Квіти на блакитному тлі” (Внизу картини $€$ малопомітні незабутки, на фоні великих яскравих квітів - півонії, лілії, троянди, на які може звернуги увагу студент). Постає питання 3 ким їх можна порівняти? Висновок: в житті, як і в природі $є$ краса, яка впадає в око, а є непомітна, яку треба розглядіти. $Є$ люди, що завжди на виду, а $є$ непомітні, та чи вони від того $є$ маловартісними? Так і на картині, ніби з цих маленьких незабуток виростає пишний букет лілій, півоній, троянд. В людині тихій, скромній треба вміти знайти багатий духовний світ.

Студентам запропоновано рефлексію над такими питаннями:

1. Чи достовірно відтворюється дійсність на картинах Білокур і в картині “Лісової пісні”?

2. Наскільки природнім є поєднання квітів, зображених художницею? А в “Лісовій пісні”, поєднання реального і казкового світу тощо?

Тому варто звернути увагу на модель навчання на основі дискусії, яка $є$ одним із характерних втілень тієї лінії дидактичних досліджень, яка пов'язана з організацією проблемного навчання, орієнтованої на творчий пошук, формування культури рефлективного мислення, всебічного розкриття кожного студента як неповторної особистості.

Серед визначальних рис дискусії можна виділити такі: групове обговорення проблем, вибір ведучих і учасників у процесі обговорення, відповідна організація місця і часу роботи, взаємодія учасників у процесі обговорення, спрямованість на досягнення навчальної мети. $€$ ряд особливих форм проведення дискусії. До них відносяться “круглий стіл”, “засідання експертної групи”, “форум”, “симпозіум”, “дебати”, “судове засідання”, “акваріум”, “асоціативне гроно”, які викладач може використовувати на заняттях літератури залежно від теми, мети і завдань заняття. Такі види навчальної діяльності варто проводити за темами (мікротемами), де студент повинен не просто засвоїти знання, але й знайти вирішення певної проблеми. Навчальна дискусія особливо необхідна при зверненні до художніх творів 3 філософською, моральною проблематикою, з героями, які стоять у ситуації вибору; до лірики, яка вирішує корінні питання буття.

Вродженість прагнень людини до моральності, прагнення правди і краси, навіть жертовності задля добра - $\epsilon$ надто поширеною, щоб іiі не помічати в людях. Вона є виявом “духу людини” [2]. К. Ушинський у свій час писав: “... начало моральності не відоме нам і не може бути відоме; бо моральність людська полягає тільки в прагненні до цього невідомого начала, але однак захоплює людину, і де б воно не проявлялося, в мистецтві, в істині чи в моральності - воно кличе людську душу вперед і вперед” [8].

Кожна людина прагне до правильності, моральності: чи то умовленні, поведінці, чи просто бажаннях. Бо моральність - це природній стан людської душі, а все природне не завжди є поміченим, так як повітря: ми ним дихаємо, не задумуючись, а от зло - явище неприродне, тому відразу помічене. Людина миттєво реагує на зло. У творах письменників бачимо наскільки більше уваги приділяється вчинкам брутальним, ганебній поведінці, моральній деградації. А все чому? Бо це видно, на це треба звернути увагу, від цього потрібно застерегти, попередити наслідки.

Викладач літератури має розвивати творчі, мистецькі здібності студентів. При цьому розвивати не тільки талановитих, обдарованих дітей, що за певних умов виховання можуть дати нашому народові чудові твори в якій-небудь галузі мистецтва, але й розвивати мистецькі здібності у молодих людей, які не обдаровані якимись мистецькими талантами. Бо саме мистецька творчість відіграє певну роль в діяльності кожної людини і часто є джерелом морального задоволення. Та в цілому в галузі мистецького виховання перше місце мусить посідати виховання смаку й розуміння свого рідного мистецтва, тим більше, що в цій галузі Україна має значні досягнення.

Григорій Ващенко зазначав, що “без естетичного виховання людина не може бути повновартісною" [1]. Але проблема естетичного виховання дуже широка і складна. Спробуємо розглянути іiі лише у зв'язку з навчанням, як проблему виховання мистецького мислення. Проте розвиток його має велике значення в загальному процесі виховання. Розвиваючи в учнів мистецьке мислення, ми разом з тим підвищуємо рівень активності їх у процесі навчання, розвитку їх моральності. Мистецьке мислення значно більше пов'язано з емоціями, ніж мислення практичне й науково-теоретичне. Тому, розвиваючи його, ми посилюємо у студентів інтерес до науки. 


\section{НЕСТАНДАРТНІ ПДХОДИ ДО ВИВЧЕННЯ УКРАЇНСЬКОЇ ЛТТЕРАТУРИ}

Отже, естетичне виховання в аспекті виховання мистецького мислення має два завдання: виховувати художній смак і розуміння краси і розвивати творчі мистецькі здібності студентів. Як зазначає Г. Ващенко, художній смак може бути вузький і широкий, примітивний i висококультурний, здоровий і хворобливий. I саме родина та вчитель має виховати смак і розуміння краси у всіх їі формах і видах, смак висококультурний і здоровий [1].

Людина у своїй слабкості потребує, щоб моральні правила були накладені на неї певним наставником, вчителем, Авторитетом. Вона все життя вчиться, іiі виховують, керують нею, бо життя складається 3 виховання і самовиховання. А все починається з сім'і, з родинного виховання. Сім'я - святиня людського духу, вихователь підростаючого покоління, плекальниця високої духовності та гуманізму, хранителька традицій та звичаїв, це вузол єднання людей у суспільстві. Тому майбутнє саме за традиційною, міцною, здоровою родиною. Велика когорта українських митців у свої творах особливу увагу приділяють проблемам родинним. Це і В. Симоненко “Лебеді материнства" та твори про рідню, В. Барка “Жовтий князь”, Л. Українка “Лісова пісня”, “Бояриня”, Л. Костенко “Маруся Чурай”, М. Матіос “Солодка Даруся”, I. Багряний “Тигролови” та багато інших. 3 великою любов’ю, 3 відповідальністю і професійністю вони піднімають гострі проблеми в сім'ї, вирішують їх на грунті християнської моралі, на базі традицій, беручи часто за основу народну культуру. Бо як у далекі від нас часи, так і тепер політика заброд, які підступно вриваються у наш самобутній світ, спрямована на руйнування сімейних цінностей, відбирання рідної мови, плюндрування самобутньої родинної культури, для збільшення прірви між батьками і дітьми, розпалювання ворожнечі між різними і водночас такими близькими регіональними частинами. Їх мета вишколити запроданців, насадити родинні чвари i створити внутрішній національний дисбаланс, бо тоді дуже легко можна такими людьми маніпулювати.

Сьогодні настав той час, коли вкрай необхідно повернутися до української родинної етнопедагогіки, до відродження традиційного статусу української родини з її непорушним авторитетом. Взірцем для нас повинен стати приклад тих країн, де дбайливо бережуть старовину, власну національну культуру. Тому й помисли спрямовані на шанобливе ставлення до предків, родинно-побутових звичаїв, традицій. Томуй не знають варварських руйнувань природи, історичних та культурних пам'яток, храмів, могил, національних святинь, рідної мови. Звичайно, що увага й повага до родини не приходить сама по собі. Її треба виховувати. Завдання педагога не просте, бо він і педагог у цьому питанні, і батько чи мати. I зобов'язаний мати різні підходи, аналізуючи ті чи інші питання, усвідомлювати себе в першу чергу як гуманітарій, сформована особистість, знавець народної культури.

Наприклад, аналізуючи твори письменників, беручи до уваги героїв і обставини, в яких вони перебувають, варто акцентувати увагу на конкретних особах, які мають власне, оригінальне обличчя, особистісне виявлення, національну і людську гідність, характер із генетичним зображенням національних рис психології, знання родоводу. Останнє - це традиційна вимога української етнопедагогіки. "Нема в світі, як родина, то вам скаже і дитина”. Знання свого родоводу дає можливість людині зробити правильний вибір життя дорослого, берегти честь свого роду і всього народу, будувати гарні, моральні стосунки з іншими людьми, зберігати і передавати 3 покоління в покоління родинні надбання та реліквії. Якщо б Чіпка Варениченко (за романом П. Мирного "Хіба ревуть воли, як ясла повні?”) знав свій родовід, або йому на це наголошували, то чи став би на шлях розбою, кровопролиття, чи хотів би так жити, як батько? Можливо, щось він би змінив, над чимось призадумався, уклав життя по-іншому. Чи, скажімо, родина Катранників, (за романом “Жовтий князь” В. Барки) знаючи історію свого роду, змогла б вчини по-іншому? Нi, вони всі, як один, відстоювали свою віру, традицію, звичай. Їх морили голодом, принижували гідність, топтали на очах хліб, руйнували церкву та не могли зруйнувати храм душі, не могли заборонити молитися, бо була сильна віра і великий послух перед батьками. Не порушувалася традиція, звичай. Людина, яка дотримується звичаїв непереможна, вона здатна завжди відстояти як свою людську, так і національну гідність. Основна ж сфера дій звичаїв - родинний побут. Звідси дитина виносить найсуттєвіші правила поведінки, їй поступово прищеплюють моральні риси: все проходить не нав'язливо, через приклад.

Розглядаючи на заняттях літератури творчість поетів, цікаво також звернути увагу на теорію поетикиекспресивностіО.ЖолковськоготаЮ.Щеглова. За цією теорією вважається, що “зміст художнього твору виникає при кожному читанні як наслідок складної взаємодії автора твору та читача [6]. Письменник розкриває ідейний задум твору, а читач інтерпретує (тлумачить) текст. 
Розуміння читачем твору залежить від багатьох чинників: знання, життєвий досвід читача, сучасне суспільне середовище 3 його соціальнополітичною атмосферою, духовне життя людини. За теорією поетики експресивності аналіз твору потрібно пов'язати не 3 тим, про що в ньому розповідається, а 3 тим, що в ньому мається на увазі" [6].

Наприклад: аналізуючи поетичний світ Ліни Костенко, заняття слід побудувати так, щоб, зупиняючись на окремих художніх деталях, афоризмах, постійних темах, контрастах, алегоричних образах, ми пізнавали ідею, яка виражає філософію письменниці, розкриває нам особистість поета, його творчі зацікавлення, i, водночас, несе в собі виховний і пізнавальний момент для читача. Для поетичного світу Ліни Костенко характерне використання афоризмів. Тексти багатьох іiі віршів розкривають важливу проблему, яка вирішується в кульмінації твору $\mathrm{i}$ має форму афоризму. “Афоризм Ліни Костенко визначає її ставлення до питань, яке завжди виражається відверто, воно інколи болісне, навіть шокуюче..." [5].

Візьмемо останні рядки вірша “Життя”, в яких автор виражає протест проти влади, проти “тепличних умов”, які позбавляють волі до боротьби.

"Як жити, зачепившись на мілкому,

то краще потонуть на мілині”.

В цьому вірші $є$ контраст, який вимальовується в двох образах плавця і потопельника, під якими різна глибина води. Образ смерті допомагає розкрити суть контрасту, який полягає в ідеї боротьби. Приємне плавання на мілині рівнозначне духовній смерті, а потопання - це сама смерть. Глибина води - це мірило труднощів в утвердженні цінностей і поглядів.

Беручи до уваги твір Л. Костенко “Берестечко”, знаходимо такі рядки:

"Поки віриш, поти й душа не піде в жебри до тривог”, “Це білий сніп душі, який горить в людині, його ж ніякий вітер не задме”, “Не допускай такої мислі, щуо Бог покаже нам неласку. Життя людського строки смислі. Немає часу на поразку”. Ці рядки заставляють нас задуматися над поняттями душа, віра, буття, поразка, біль, плинність часу. Всіх їх об'єднує основа людського життя - душа, яка виступає головним чинником поведінки людини. “Кожен є тим, чиє серце в ньому” (Г. Сковорода). "Насправді шляхетна людина, - писав Петрарка, - не народжується 3 великою душею, але сама себе робить такою величними своїми ділами". Довгі роки бездуховності витіснили з людини Бога, а його місце посів раб. Творчість Ліни Костенко допомагає людині витіснити із себе раба, стати особистістю, схилитись до добра, не боятися поразок, бо ніяка перемога не вчить так, як поразка. Варто також звернути увагу на дослідження творчості В. Симоненка Іваном Кошелівцем, який, вважаючи Василя Симоненка оригіналом 3 особливою поетичною індивідуальністю, звертав увагу на нешаблонність, на духовне новаторство у творчості шістдесятника.

Наприклад, у вірші “Жорна” рядки на Ж, де присутня звукова гама шиплячих. Уважним був Симоненко і до семантики слова: "I сіялось не борошно, а мука...". Автор навмисне ставить наголос на слові мука, заставляючи читача працювати над текстом, зрозуміти інтригу, розвинути уяву. Так як і в творчості Ліни Костенко у Василя Симоненка $є$ багато афоризмів, які засвідчують високу свідомість, духовність і моральність людини: “Цілую руки, щзо крутили жорна у переддень космічної доби”, “I жити спішити треба, гляди ж не проспи”, “Їйправо, не страшно вмерти, а страшно мертвому жить".

Багато таких рядків можна знайти у поета, i кожен - це глибинний розум, перевірений $\mathrm{i}$ доказаний життям. Адже література, більше ніж будь-яка дисципліна, допомагає студентам спілкуватися на пізнавальному й етичному рівні як з героями, носіями певних морально-етичних норм, так і з іншими суб'єктами, які беруть участь в осмисленні життєвих проблем “ викладачем і своїми однолітками.

Ще, скажімо, одним $з$ нестандартних підходів до вивчення тої чи іншої теми - є робота вдома та рефлексивна діяльність, визначальними моментами якої $є$ : усвідомлення суб'єктом засобів та основ діяльності, їхньої зміни; вихід у зовнішню позицію одного суб' єкта діяльності стосовно діяльності іншого суб'єкта; процес відображення однією людиною “внутрішньої картини світу” іншої людини; самоаналіз; осмислення людиною закономірностей, механізмів власної діяльності та існування. Це може бути i пошукова робота самого студента, а може бути скерована викладачем. Скажімо, можна запропонувати створити дискусію, розподілити ролі (ця форма допоможе найкраще розкрити здібності студентів, спрямувати хід дискусії в необхідному напрямку); створити проект на запропоновану тему дослідницького характеру, що в свою чергу розвине вміння працювати у команді, колективі, створюватиме творчу лабораторію. 


\section{НЕСТАНДАРТНІ ПДХОДИ ДО ВИВЧЕННЯ УКРАЇНСЬКОЇ ЛТЕРАТУРИ}

Особливістю нестандартних занять - $є$ перш за все індивідуальний підхід до студентів, до їх потреб, їх світогляду. Такі заняття покликані зацікавити, знищити байдужість, навчити жити і любити, діяти i шукати, знаходити i вдосконалювати. Студенти самі часом прагнуть щось створити своє, індивідуальне, відкриваючи себе для себе і для інших.

Характерними рисами сучасного педагога мають бути глибокі знання своєї спеціальності у поєднанні з методичною майстерністю, розуміння особливостей розвитку молоді, їхнього внутрішнього світу, бажання і вміння спілкуватися 3 ними, сучасне науково-педагогічне мислення, готовність до постійної самоосвіти, поглиблення і поповнення знань.

Висновки. Таким чином, ефективність використання інноваційних методів навчання в контексті вивчення української літератури значно урізноманітнить традиційні (що стали вже добре відомими) методи, прийоми, види навчальної діяльності, а також істотно підвищить активізацію самостійної роботи студентів, стимулюватиме їх до систематичного навчання, підвищення рівня якості знань і водночас-здорова конкуренція між студентами сприятиме всебічному розвитку особистості.

Прекрасним засобом виявлення уваги до літератури є усунення формалізму, шаблонності, бездушності та ігнорування психологічних, індивідуальних властивостей молоді. Як у кожній дисципліні, так і в літературі, велике значення має добір матеріалу. Письменство - це велике мистецтво, тому у ньому велику роль відіграють емоції, а особливо емоція естетична. У наш час, коли дитина прикута до комп'ютера, коли її оточує інформаційний хаос, а за вікном бруд i брутальність, до неї потрібний особливий підхід. Теперішне життя $з$ його клопотами, турботами, переживаннями створює такі умови для людини, в котрих вона часто закривається від світу, подібно мушлі. Потрібно віднайти в собі сили для подвигу в ім'я людини, бо це найпрекрасніше створіння на землі. Як стверджували древні: “Пізнай самого себе - і ти пізнаєш світ".

\section{ЛІТЕРАТУРА}

1. Ващенко Г. Виховний ідеал: Підручник для педагогів, виховників, молоді і батьків. Т. 1 / Г. Ващенко. - Полтава:Полтавський вісник, 1994. - 191 с.

2. Вишневський О. Сучасне українське виховання. / О. Вишневський// У пошуках нових підходів. - Львів, 1999. - №10. - С. 31.

3. Кларин М. В. Инновационные модели обучения в зарубежных педагогических поисках. / М. В. Кларин. - M.:-1994.-C. 129-131.
4. Кларин М. В. Инновации в мировой педагогике. / М. В. Кларин. - Рига, 1995. - 176 с.

5. Кошаровська Г. Д. Творчість Ліни Костенко. / Г. Кошаровська. К.: “КМ Academia”, 1994.-С. 15 - 21.

6. Пентилюк М. І. Методика навчання рідної мови в середніх навчальних закладах: підручник для студентів філологів вищих закладів освіти / М.І. Пентилюк, А.Г. Галетова та ін.; За ред. М. І. Пентилюк. - К.: Ленвіт, 2000. -264 c.

7. Степанишин Б. Викладання української літератури в школі: Методичний посібник для вчителя. / Б.І. Степанишин. - К.:Просвіта, 1995. - 254 с.

8. Ушинський К. Д. Твори в шести томах. Т. 1: Педагогічні статті /К. Д. Ушинский. - К.: Учпедвидав 1954. $-364 \mathrm{c}$

9. Фомич I. І. Дискусія в системі інноваційного навчання української літератури в школі / І. Фомич. Вісник Запорізького державного університету: Філологічні науки. -2000. - №1. - С. 208 - 2011.

\section{REFERENCES}

1. Vashchenko, H. (1994). Vykhovnyi ideal: Pidruchnyk dlia pedahohiv, vykhovnykiv, molodi $i$ batkiv [Educational ideal: A textbook for educators, students, youth and parents]. Poltava: Poltavskyi visnyk, 191 p. [in Ukrainian].

2. Vyshnevskyi, O. I. (1996). Suchasne ukrainske vykhovannia [Modern Ukrainian education]. U poshukakh novykh pidkhodiv [Searching the new approaches]. Lviv, No. 10, p. 31. [in Ukrainian].

3. Klarin, M. V. (1994). Innovatsionnye modeli obucheniya $v$ zarubezhnykh pedagogicheskikh poiskakh [Innovative models of teaching in foreign pedagogical searches]. Moscow: Arena, pp. 129-131. [in Russian].

4. Klarin, M. V. (1995). Innovatsii v mirovoy pedagogike [Innovations in world pedagogy]. Riga: Experiment, 176 p. [in Russian].

5. Kosharovska, H. D. (1994). Tvorchist Liny Kostenko [Creativity Lina Kostenko]. Kyiv: KM Academia, pp.15-21. [in Ukrainian].

6. Pentyliuk, M. I. \& Haletova, A. H. (2000). Metodyka navchannia ridnoi movy v serednikh navchalnykh zakladakh [The method of teaching mother tongue in secondary schools]. Kyiv: Lenvit, 264p. [in Ukrainian].

7. Stepanyshyn, B. I. (1995). Vykladannia ukrainskoi literatury v shkoli: metodychnyi posibnyk dlia vchytelia [Teaching Ukrainian literature at school: tutorial for a teacher]. Kyiv: Prosvita, 254 p. [in Ukrainian].

8. Ushynskyi, K. D. (1954). Tvory v shesty tomakh [Works in six volumes]. Vol.1, Pedagogical articles. Kyiv: Uchpedvydav, 364 p. [in Ukrainian].

9. Fomych, I. I. (2000). Dyskusiia v systemi innovatsiinoho navchannia ukrainskoi literatury $v$ shkoli [Discussion in the system of innovative teaching of Ukrainian literature at school]. Bulletin of the Zaporizhzhya State University: Philological Sciences. No.1, pp.208 - 2011. [in Ukrainian].

Стаття надійшла до редакції 09.11.2018 